\title{
Responsiveness of people with moderate and significant intellectual disability to physical stimulation
}

\author{
Marzena Ślężyńska', Grzegorz Mięsok', Kamila Mięsok² \\ ${ }^{1}$ Academy of Physical Education, Katowice, Poland \\ 2 Educational-Revalidational Aggregate School Institution, Wlodzislaw, Silesia, Poland
}

Ślężyńska M, Mięsok G, Mięsok K. Responsiveness of people with moderate and significant intellectual disability to physical stimulation. Ann Agric Environ Med. 2018; 25(1): 13-22. doi: 10.5604/12321966.1233560

\begin{abstract}
Objective. The aim of the research was to verify whether intellectually disabled people are responsive to motor stimulation, and whether the specific physical exercises, besides traditional rehabilitation and occupational therapy, would result in physical fitness enhancement.

Materials and methods. The research was carried out on 259 persons with moderate and significant intellectual disability, participants of occupational therapy workshops. They were divided into two groups: a control group that underwent traditional rehabilitation treatment and occupational therapy, and an experimental group that additionally performed feasible physical exercises for 10 months. Participants' body mass and height were measured to calculate their body mass index (BMI). Physical fitness was assessed with the Eurofit Special test and additional balance tests, at the beginning and at the end of the experiment.

Results. The results showed that the body mass of both men and women increased in the control group, and was reduced in the experimental group. The results of the physical fitness tests were more varied, in which the control group obtained similar results in the repeated measurements, and the experimental group significantly improved the initial results after 10 months of performing the feasible physical exercises.

Conclusions. The applied physical exercises performed in the experimental group were effective because they caused body mass loss and significant improvement in physical fitness.
\end{abstract}

\section{- Key words}

intellectual disability, somatic features, physical fitness

\section{INTRODUCTION}

Moderate intellectual disability is characterized by memory deficits, often speech impediments, limited vocabulary and thinking in pictures and concrete images. People with intellectual disabilities show a strong need for social relations. They can take care of their personal hygiene and grooming, perform simple housework and gainful activities, and eagerly cooperate with other persons. More physically fit people take part in sport straining and Special Olympics.

Significant intellectual disability is characterized by very slow perception, short-term memory, limited attention focused only on strong stimulus. Persons with significant intellectual disability have speech articulation disorders, often use very simple or two-word sentences. They show behaviour disorders and strong attachment to people and objects. They are independent in using a toilet and eating, but have limited physical mobility.

People with moderate and significant intellectual disability predominantly take part in occupational therapy workshops based on the resolution about vocational and social rehabilitation of disabled persons (1997), and on the regulation of the Ministry of Economy, Labour and Social Policy about occupational therapy workshops (2004). Only

Address for correspondence: Marzena Ślężyńska, Academy of Physical Education Mikołowska 72, 40-065 Katowice, Poland

E-mail: marzena.slezynska@wp.pl

Received: 8 June 2014; accepted: 10 March 2015; first published on February 2017 persons recognized as disabled and with the prescribed necessity of participating in occupational therapy are admitted to occupational therapy workshops.

The objective of the workshops is the vocational and social rehabilitation of intellectually disabled persons. They are designed to help their participants restore or gain the necessary skills that enable the employment of disabled persons, or their further participation in professional trainings, and also to acquire daily life skills to gain greater self-reliance.

The workshops offer different kinds of classes, and helps to select them according to the participant's interests. Duration time of the workshops is about $35 \mathrm{~h}$ per week. The most commonly chosen classes are the computer workshop, pottery, paper art, weaving and sewing, home economics, woodwork, handicraft, applied arts, rehabilitation and social skills.

The initial research showed significant differences between subjects with significant and moderate intellectual disability in all physical fitness tests (Ślężyńska et al., 2013). The aim of the repeated tests was to verify whether subjects with moderate and significant disability are responsive to physical stimulation, and whether the feasible physical exercises besides traditional rehabilitation and occupational therapy - are going to be effective in physical fitness improvement. 


\section{MATERIALS AND METHOD}

The initial and repeated research was carried out on 121 women and 138 men with moderate and significant intellectual disability, participants of occupational therapy workshops (OTW). They were divided into a control group (C) who underwent traditional rehabilitation treatments and occupational therapy - OTW (Racibórz, CzerwionkaLeszczyny, Rybnik, Żory), and an experimental group (E) (JastrzębieZdrój, WodzisławŚląski) who additionally underwent feasible physical training for 10 months between September 2012 - June 2013 (Tab. 1). Comparison of the initial and repeated research results constituted the essential part of the experiment.

Table 1. Age and number of intellectually disabled persons taking part in the research

\begin{tabular}{|c|c|c|c|c|c|c|}
\hline \multirow{2}{*}{ Group } & \multirow{2}{*}{ Symbol } & \multicolumn{2}{|c|}{ Women } & \multicolumn{2}{|r|}{ Men } & \multirow[t]{2}{*}{ Total } \\
\hline & & Number & Average age & Number & Average age* & \\
\hline \multicolumn{7}{|c|}{ Moderate intellectual disability } \\
\hline Control & C & 57 & 30.2 & 50 & 30.0 & 107 \\
\hline Experimental & E & 11 & 27.4 & 23 & 29.1 & 34 \\
\hline \multicolumn{7}{|c|}{ Significant intellectual disability } \\
\hline Control & $\mathrm{C}$ & 34 & 32.1 & 48 & 31.4 & 82 \\
\hline Experimental & E & 19 & 34.5 & 17 & 30.9 & 36 \\
\hline
\end{tabular}

* Average age of the participants at the beginning of the experiment (June 2012)

Participants' body mass and height measurements. with $1 \mathrm{~cm}$ and $1 \mathrm{~kg}$ accuracy. were taken to calculate their body mass index (BMI). Physical fitness was assessed with Eurofit Special test (Skowronski et al., 2009), and additional balance tests at the beginning and at the end of the experiment after 10 months.

The Eurofit Special test consists of 6 trials:

1) Walking on a gym bench in straight body position (points) - balance test (Fig. 1).

2) Standing long jump (cm) - explosive strength. jumping ability test (Fig. 2). Performing two test jumps and two assessed jumps.

3) Throwing a $2 \mathrm{~kg}$ medicine ball with thestronger arm $(\mathrm{cm})$ - strength. motor coordination test (Fig. 3).

4) 25 meter run from standing start (sec.) - speed test (Fig. 4)

5) Forward body bending in long sit $(\mathrm{cm})$ - suppleness test (Fig. 5).

6) Supine to long sitting position bends with elbows touching the knees in each repetition in $30 \mathrm{sec}$. (maximal sit-ups number) - abdominal muscle strength test (Fig. 6).

Balance was assessed with three additional tests:

1) Rising up on tip-toes with eyes open or eyes closed (sec) - static balance (Fig. 7, 8).

2) Walking along a 5meter line with heel-to-toe steps (sec) dynamic balance (Fig. 9).

Measurement data of somatic and motor abilities were subjected to statistical computations (Nisbet et al., 2009). Arithmetic mean (x), standard deviation (s) and variation coefficient (v) were calculated with Statistica programme. Relevance in variables was checked by analysis of variance (ANOVA) with repeated measurements and post-hoc Tuckey multiple comparison tests for numerical instabilities. Level of materiality was $\mathrm{p}<0.05$.

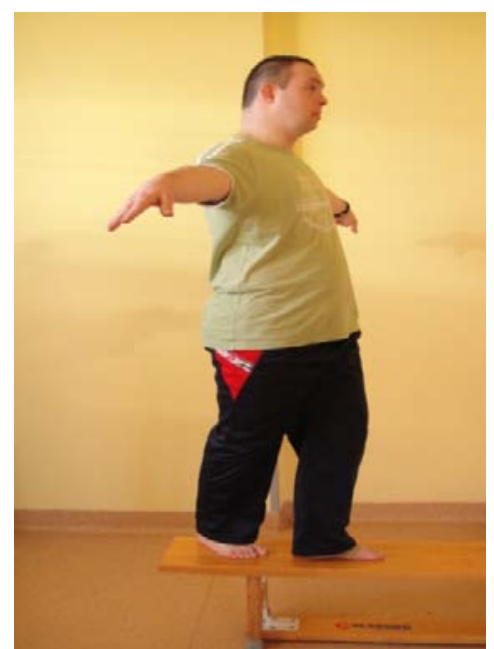

Picture 1. Walking on a gym bench in straight body position (points) - balance test

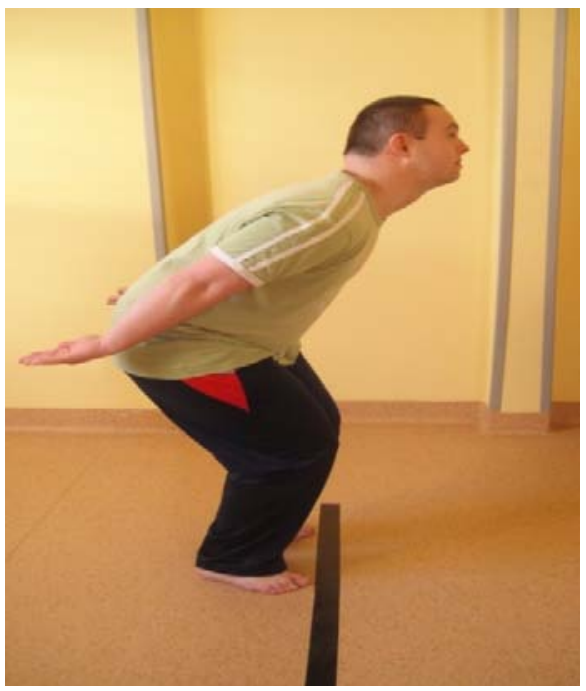

Picture 2. Standing long jump $(\mathrm{cm})$ - explosive strength jumping ability test

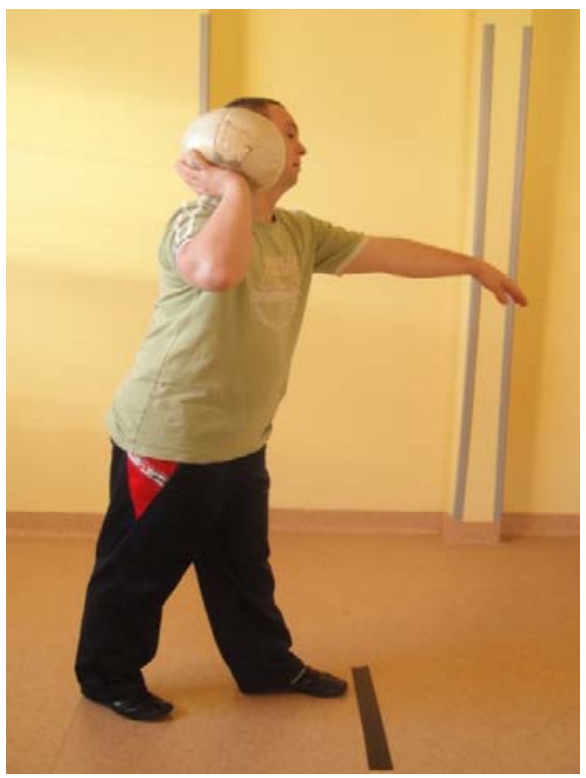

Picture 3. Throwing a $2 \mathrm{~kg}$ medicine ball with the stronger arm $(\mathrm{cm})$ - strength. motor coordination test 


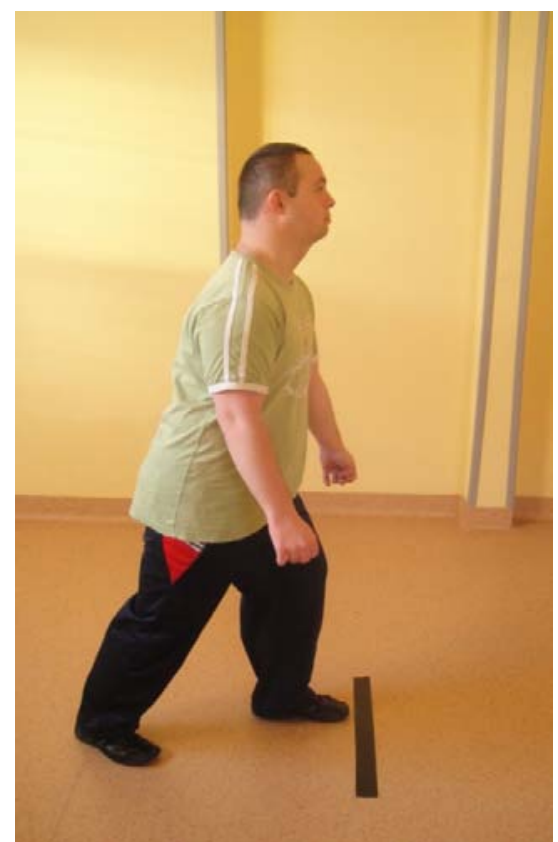

Picture 4. 25 meter run from standing start (sec) speed test

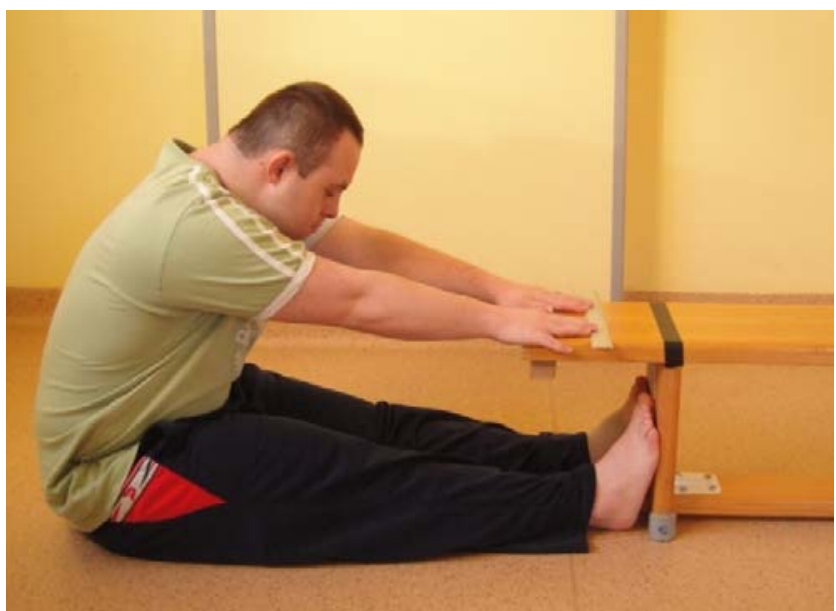

Picture 5. Forward bending in long sit (cm) - suppleness test

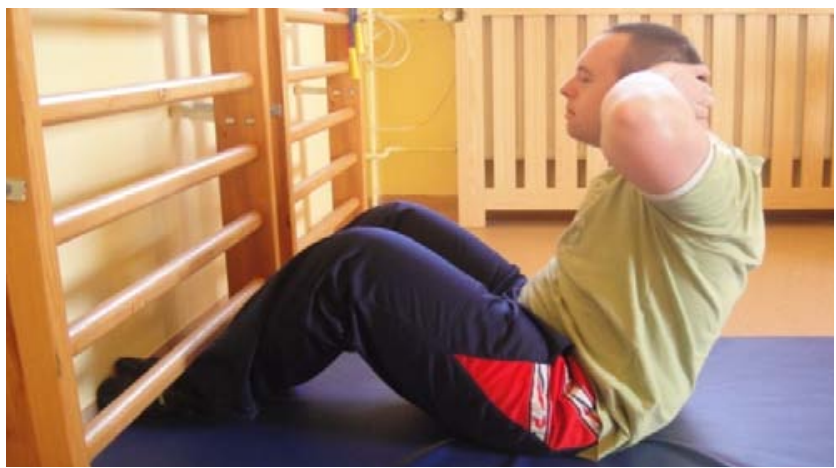

Picture 6. Supine to long sitting position. bending with elbows touching the knees in each repetition in $30 \mathrm{sec}$ (maximal bends number) - abdominal muscle strength test
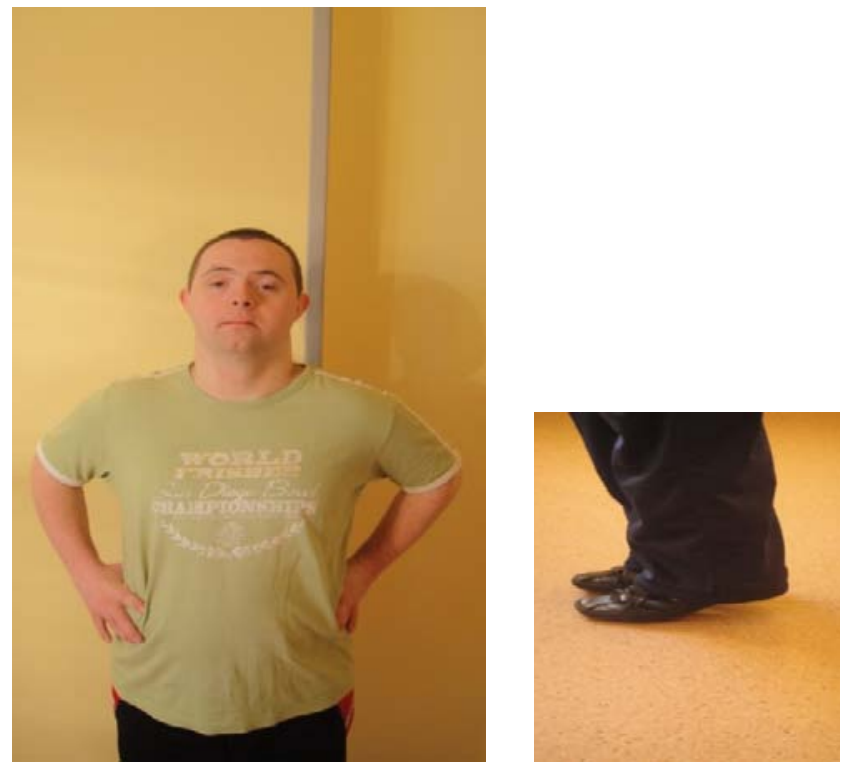

Picture 7. Rising up on tip-toes with eyes open - static balance
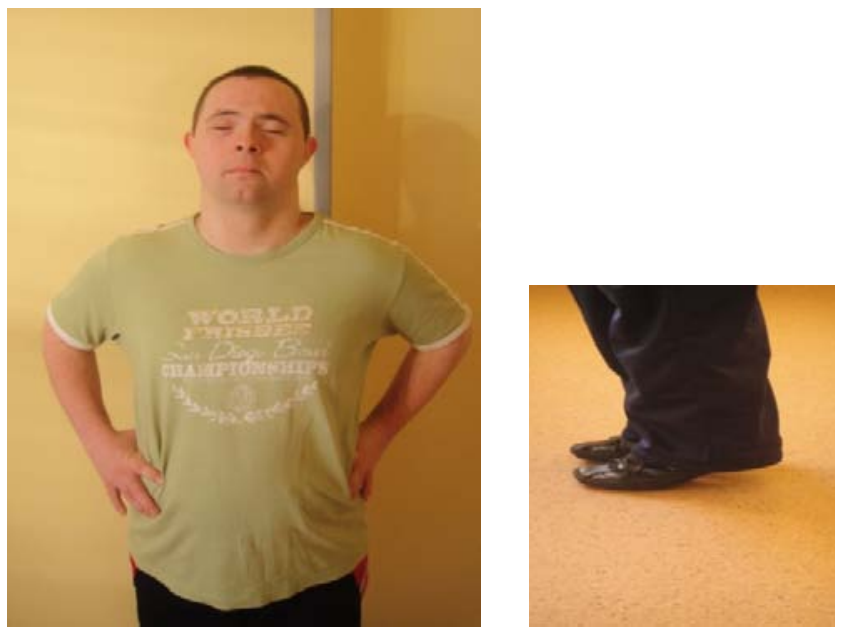

Picture 8. Rising up on tip toes with eyes closed - static balance
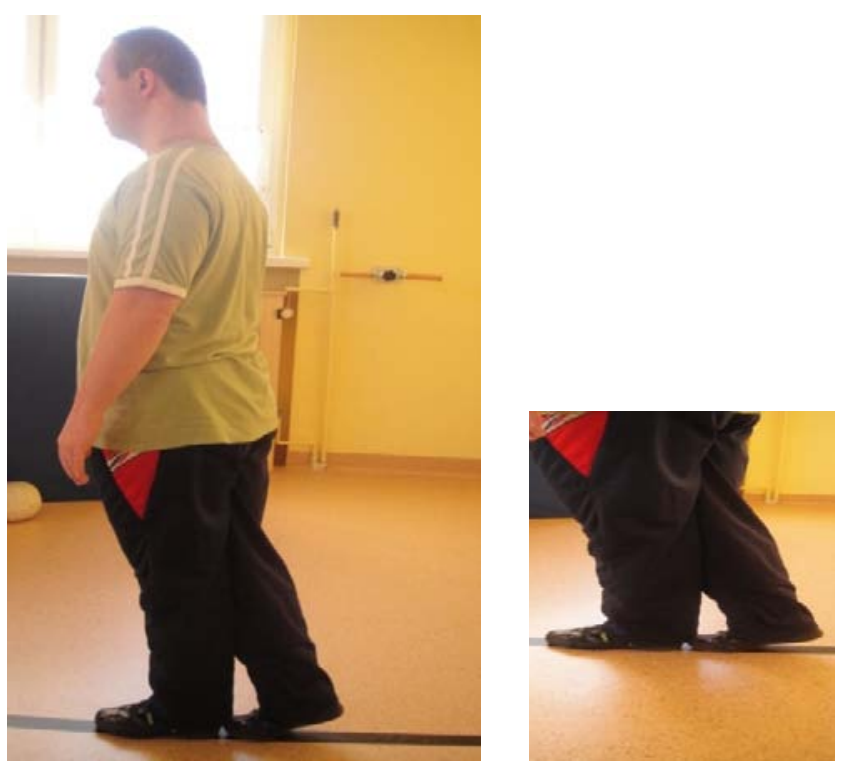

Picture 9. Walking along a 5 meter line with heel-to-toe steps (sec) - dynamic balance 


\section{RESULTS}

Body height during the experiment remained unchanged and in the women's control group with moderate intellectual disability it was $161.81 \pm 8.76 \mathrm{~cm}$, and in the experimental group $-160.64 \pm 8.27 \mathrm{~cm}$. In the control group with significant intellectual disability it was $157.47 \pm 7.80 \mathrm{~cm}$ and in the experimental group - $159.21 \pm 9.41 \mathrm{~cm}$.

Body mass in women (Fig. 1) increased significantly in the control group with moderate and significant disability $1.02 \mathrm{~kg}$ and $1.18 \mathrm{~kg} ; \mathrm{p}=0.0002$; whereas in the experimental group with moderate disability it decreased $(-1.18 \mathrm{~kg} ; \mathrm{p}=0.08)$, and in the group with significant disability body mass the loss was even more statistically significant ( $1 \mathrm{~kg} \cdot \mathrm{p}=0.022)$.

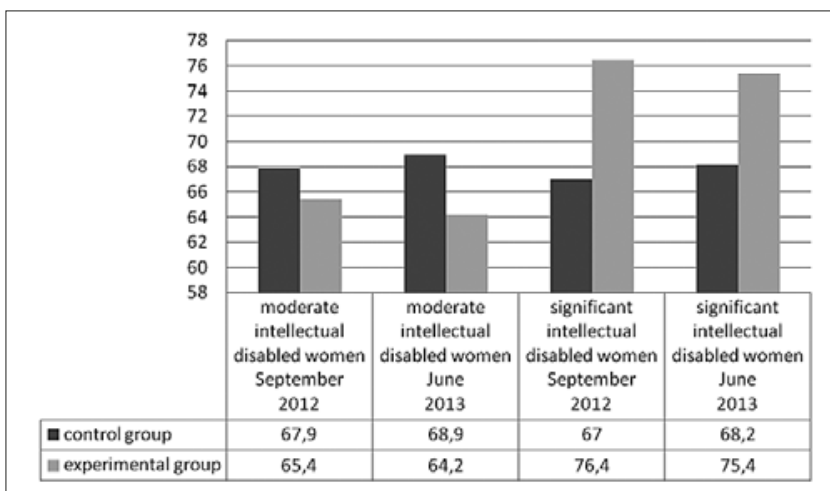

Figure 1. Body mass

As a consequence, body mass index (BMI) was changed, and in the control group with moderate disability it was significantly changed ( 0.40 points and 0.47 points; $\mathrm{p}=0.0002)$. In the experimental group with moderate disability, it was insignificantly changed $(-0.43$ points; $p=0.134)$, and in the group with significant intellectual disability a substantial change was observed ( -0.42 points; $\mathrm{p}=0.015)$ (Tab. 2 ; Fig. 2). Therefore, it was observed that the physical exercises performed in the experimental group were effective because they caused body mass loss and lower body mass index.

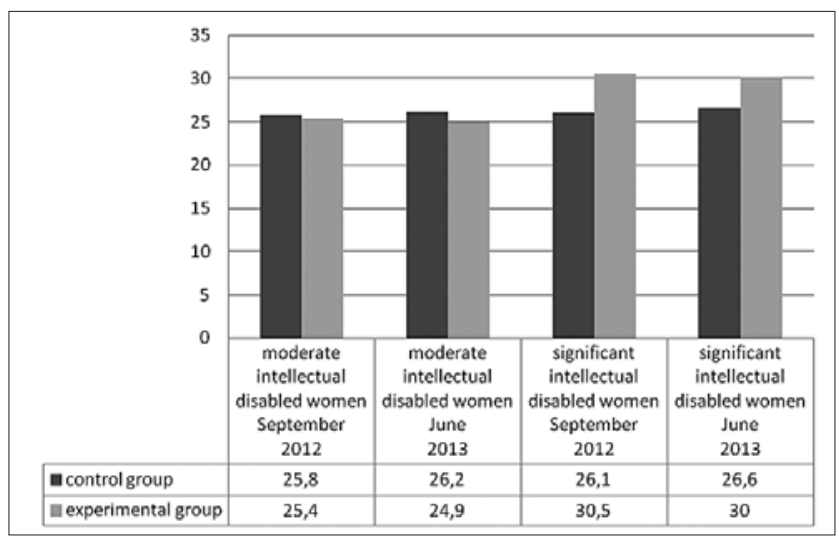

Figure 2. Body mass index (points)

Physical fitness tests revealed more differences in the tested women, although the least differences were seen in walking on a gym bench test, and they were often insignificant (Fig. 3). Further observations revealed that the above trial did not show significant differences in the tested subjects. Therefore, to evaluate the balance, more diagnostic tests had to be performed, e.g. rising up on tip-toes.

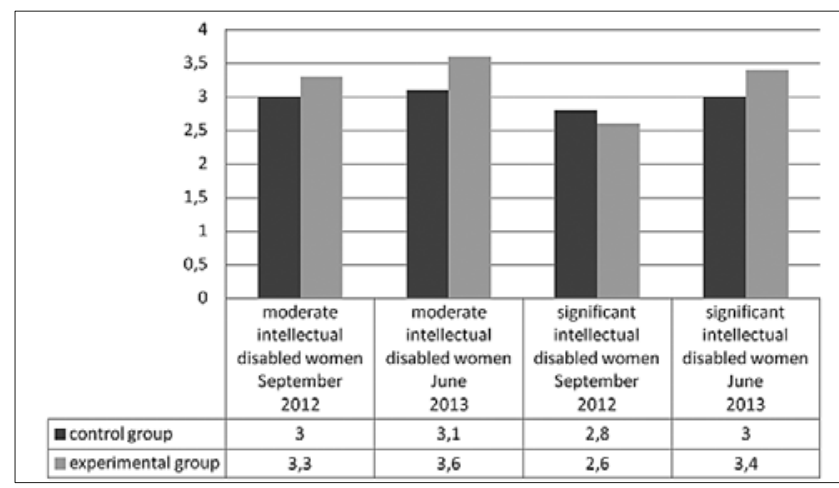

Figure 3. Walking on a gym bench (points)

The standing long jump (explosive strength) (Fig. 4) clearly showed the effectiveness of the additional exercises, since in women in the control group with moderate disability a slight decrease of the initial results was noticed (about $-2.03 \mathrm{~cm}$; $\mathrm{p}=0.01$; and $-4.14 \mathrm{~cm} ; \mathrm{p}=0.353$ ). The experimental group achieved statistically significant progression in jumping ability (13.18 cm; p=0.0001, and $11.69 \mathrm{~cm} ; \mathrm{p}=0.006)$.

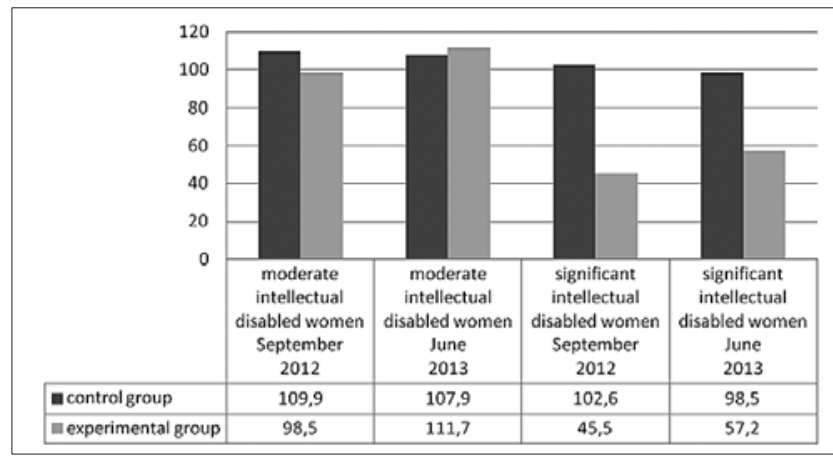

Figure 4. Standing long jump (cm)

In the $2 \mathrm{~kg}$ medicine ball throwing test (strength), similar tendencies were observed (Fig. 5). Women in the control group with moderate disability showed improvement in their test results $(0.43 \mathrm{~cm} ; \mathrm{p}=0.997)$, and in women with significant disability, slightly worse results were obtained $(-4.70 \mathrm{~cm}$; $\mathrm{p}=0.879$ ). Women with moderate and significant intellectual disability in the experimental group showed substantially better results compared to the initial tests $(43.91 \mathrm{~cm}$; $\mathrm{p}=0.0001$; and $37.42 \mathrm{~cm} ; \mathrm{p}=0.0004)$.

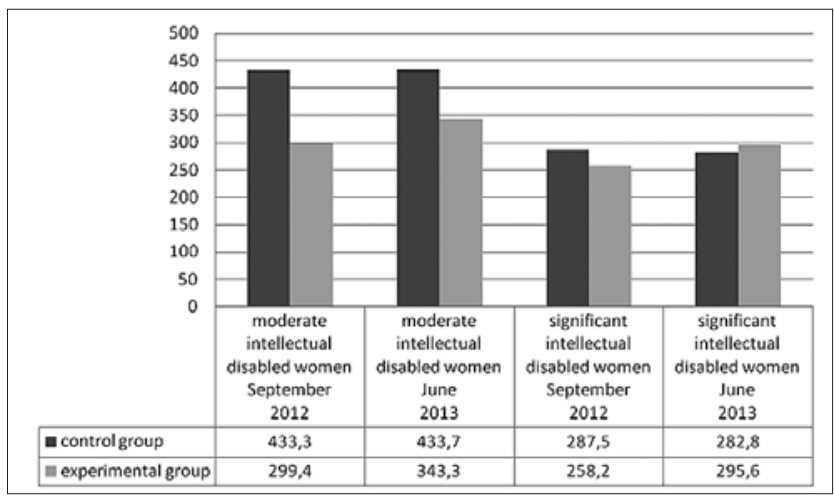

Figure 5. Throwing a $2 \mathrm{~kg}$ medicine ball $(\mathrm{cm})$ 
In the 25 meter run (speed) test, significant differences were observed in women (Fig. 6). Speed test results in women with moderate and significant intellectual disability were deteriorated in comparison to the initial results $(0.25 \mathrm{sec}$. $\mathrm{p}=0.0003 ; 0.48$ sec.. $\mathrm{p}=0.002)$. In contrast. women in the experimental group with moderate and significant intellectual disability ran the 25 meter distance in a significantly shorter time after 10 months $(-0.41$ sec., $\mathrm{p}=0.010 ;-1.07 \mathrm{sec}$., $\mathrm{p}=0.0001)$.

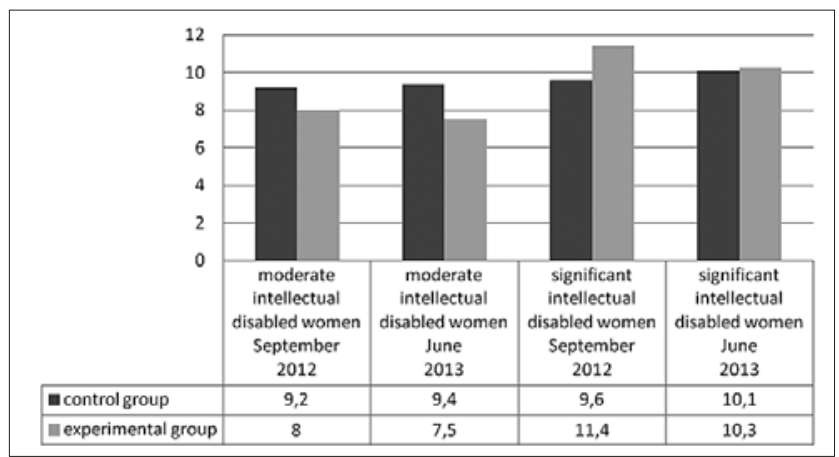

Figure 6. 25 meter run (sec)

The above-observations were also confirmed in long sitting forward bend test (flexibility) (Fig. 7). Deterioration of the results was seen in women in the control group with moderate and significant disability $(-0.76 \mathrm{~cm} . \mathrm{p}=0.233$; and $-1.44 \mathrm{~cm} . \mathrm{p}=0.015)$, whereas in the experimental group the initial results were substantially improved $(5.45 \mathrm{~cm}$ and $4.79 \mathrm{~cm} ; \mathrm{p}=0.0001)$.

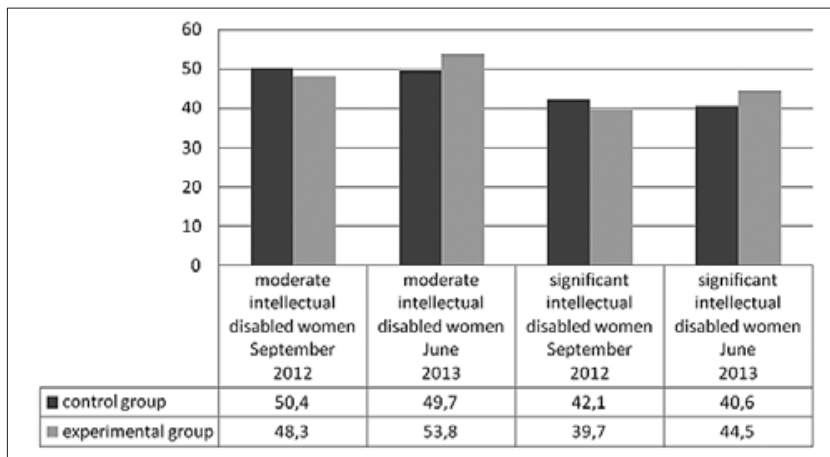

Figure 7. Forward bending in long sit (cm)

Analogical observations were made in the abdominal muscle strength test (supine to long sit) (Fig. 8). Women in the control group with moderate and significant intellectual disability performed less sit-ups $(-1.27 . \mathrm{p}=0.0001$; and -0.73 . $\mathrm{p}=0.050)$, whereas women in the experimental group with analogical intellectual disabilities performed a substantially bigger number of sit-ups (2.91 and 2.31; $\mathrm{p}=0.0001$ ).

Similar tendencies were seen in balance tests (Fig. 9, 10). Women in the control group with moderate disability were able to keep their balance for a significantly shorter time in the rising up on tip toes-test with eyes closed and open $(-2.86$ sec.; $\mathrm{p}=0.0001$ and -0.50 sec.; $\mathrm{p}=0.195 ;-1.21$ sec.; $\mathrm{p}=0.008$ and -0.15 sec.; $\mathrm{p}=0.95$ ).

Comparable observations were made in the walking test along a 5 meter line with heel-to-toe steps (Fig. 11). Women in the control group with moderate and significant intellectual disability performed this test in a slightly longer time (1.12 sec.; $\mathrm{p}=0.0008$; and $0.21 \mathrm{sec}$; $\mathrm{p}=0.978)$, whereas women in

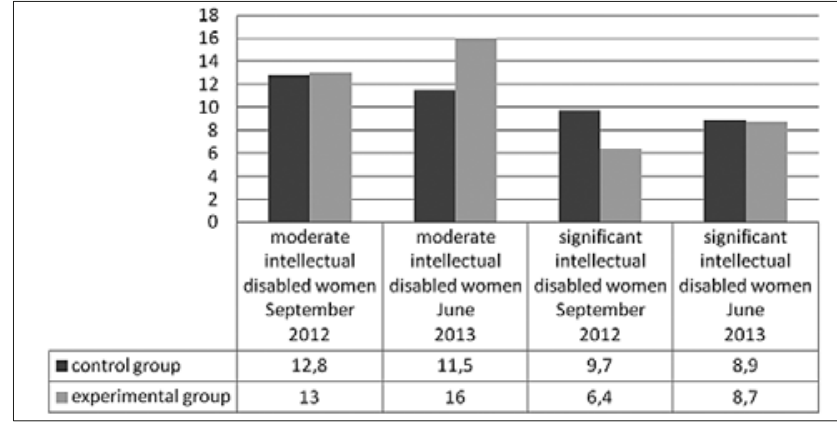

Figure 8. Supine to long sit (sit-ups number)

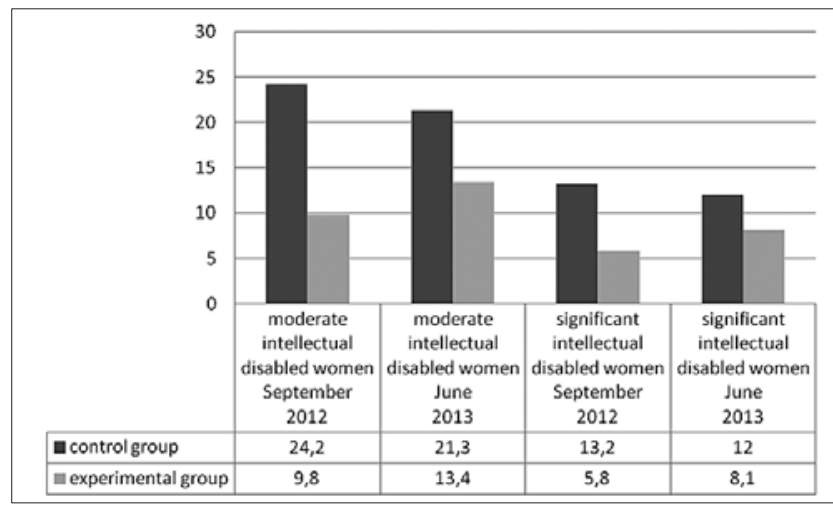

Figure 9. Rising up on tip toes with eyes open (sec)

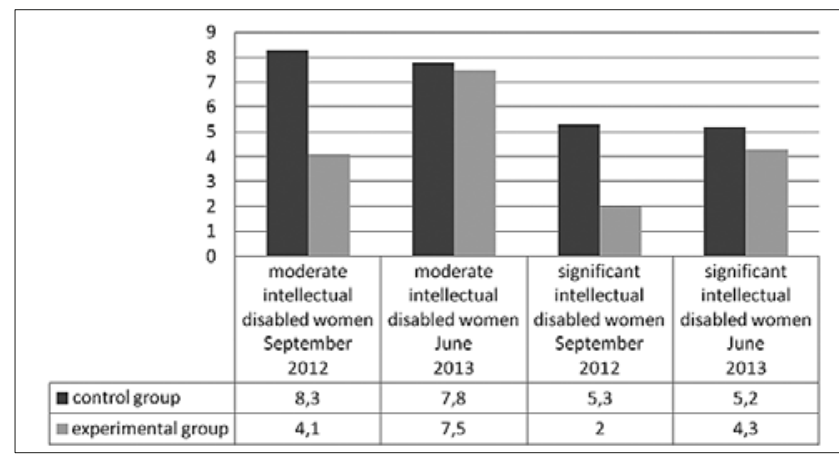

Figure 10. Rising up on tip toes with eyes closed (sec)

the experimental group walked the line in a significantly shorter time ( -3.18 sec.; $\mathrm{p}=0.0001$; and -3.57 sec.; $\mathrm{p}=0.0001)$, which proved their better coordination.

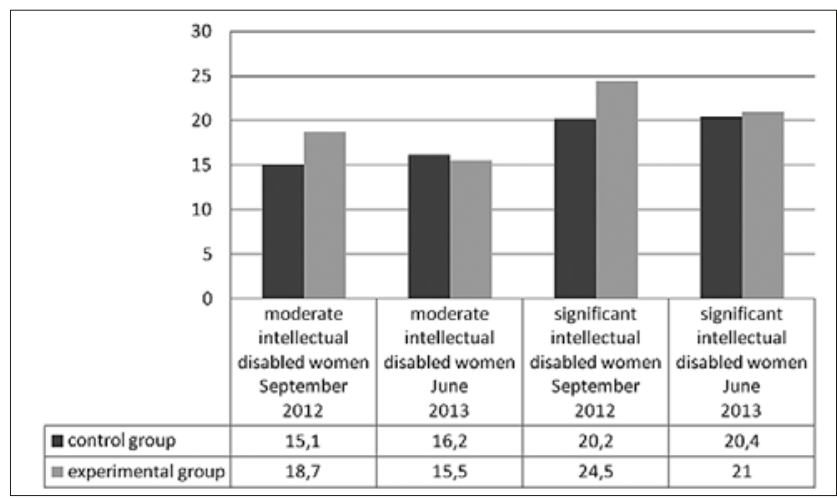

Figure 11. Walk on 5 meter line with heel-to-toe steps (sec)

In conclusion. it can be stated that all the feasible exercises proved to be effective. Women in the experimental group (E), 
in almost every fitness and equivalent tests obtained better results in the repeated trial after 10 months.

Body height in men during the experiment, as well as in women, remained unchanged $-171.8 \pm 9.23 \mathrm{~cm}$ for the control group with moderate disability, $172.5 \pm 10.7 \mathrm{~cm}$ for the experimental group, and $169.9 \pm 9.5 \mathrm{~cm}$ and $168.8 \pm 12.1 \mathrm{~cm}$ for the significantly disabled, respectively. Body height differences in the compared groups were insignificant; however, changes in body mass were substantial.

A significant increase in body mass (Fig. 12) was observed in men with moderate disability in the control group $(0.74 \mathrm{~kg}$. $\mathrm{p}=0.0001$ ), whereas it was significantly decreased in the experimental group $(-0.86 ; \mathrm{p}=0.004)$. Similar tendencies were seen between the control and experimental groups with significant intellectual disability $(1.06 \mathrm{~kg} ; \mathrm{p}=0.0001$; $-0.77 \mathrm{~kg} ; \mathrm{p}=0.099$ ).

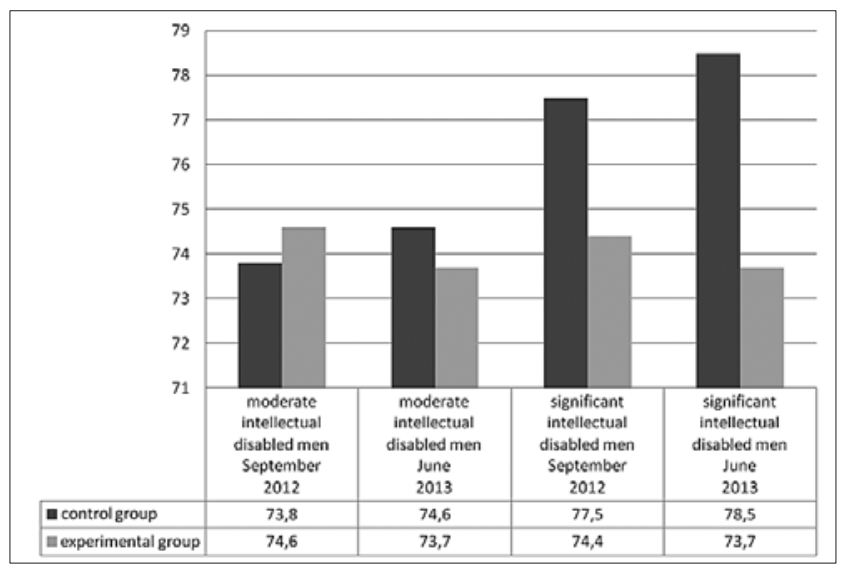

Figure 12. Body mass $(\mathrm{kg})$

Consequently, body mass index in the control group was slightly higher ( 0.43 points and 0.36 points), and in the experimental group was lower $(-0.27$ points and -0.25 points) (Fig. 13). This can indicate that the physical exercises proved to be effective since body mass was certainly substantially reduced as a result of increased metabolism.

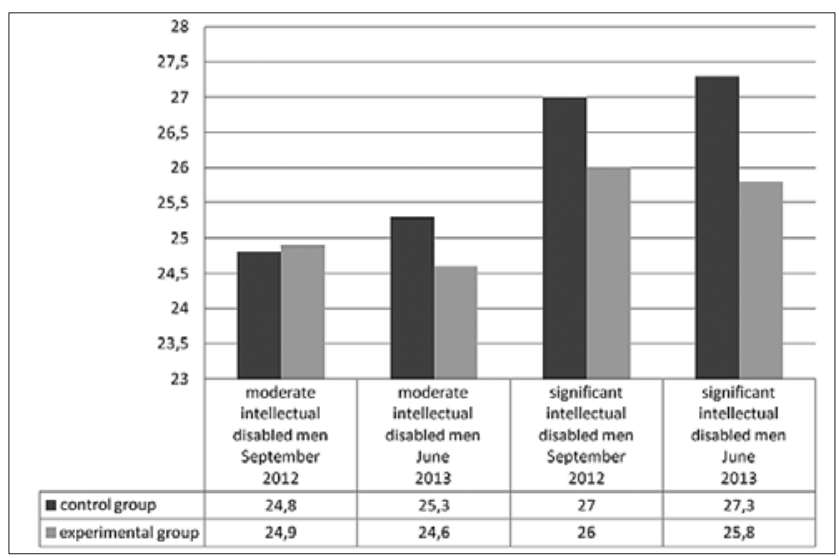

Figure 13. Body mass index (points)

The study fully confirmed that people with moderate and significant intellectual disabilities are responsive to motor stimulation.

More significant results of 10 months physical activity in men - although not as significant as in women - were observed in fitness tests.
Greater progression in walking along a gym bench test (Fig. 14) were seen in the experimental group ( 0.68 point; $\mathrm{p}$ $<0.0001 ; 0.77$ point; $\mathrm{p}<0.0002)$ than in the control group (0.24 point; $\mathrm{p}<0.04 ; 0.27$ point; $\mathrm{p}<0.03$ ).

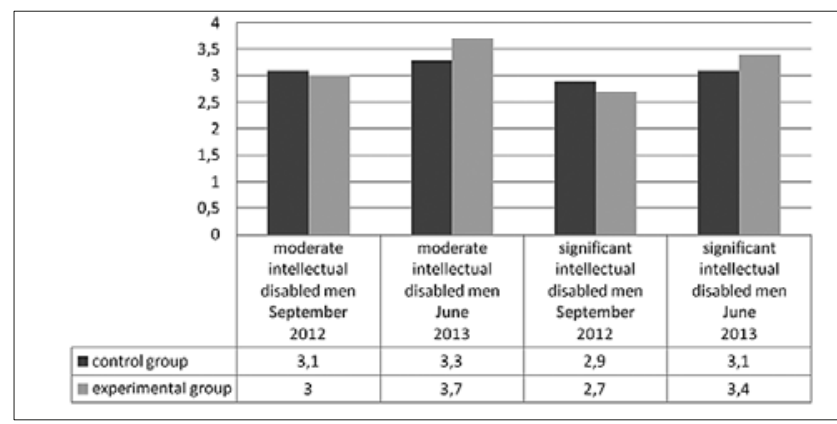

Figure 14. Walking on a gym bench in straight body position (points)

A slight deterioration in the results $(-0.79 \mathrm{~cm}$ and $-2.08 \mathrm{~cm})$ was noted in the control group with both intellectual disabilities in the standing long jump (explosive strength), whereas significant progress was seen in the experimental group (14.78 cm and $9.64 \mathrm{~cm} ; \mathrm{p}=0.0001)$ (Fig. 15).

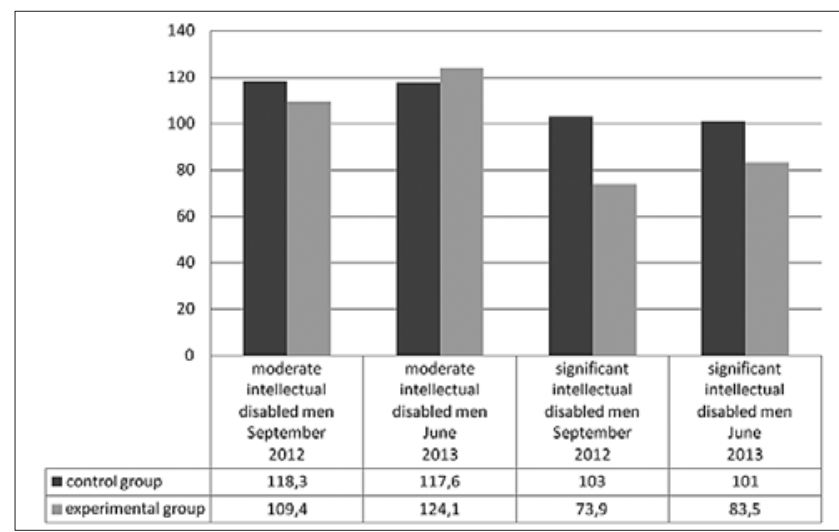

Figure 15. Standing long jump (cm)

Similar tendencies were observed in the medicine ball throwing (strength. coordination) (Fig. 16). The control group with moderate and significant disabilities performed similar or shorter throws in the repeated trials $(10.21 \mathrm{~cm}$ and $-5.29 \mathrm{~cm} ; \mathrm{p}=0.044)$, whereas the experimental group obtained significantly better results $(42.41 \mathrm{~cm} ; \mathrm{p}=0.004$ and $20.35 \mathrm{~cm} ; \mathrm{p}=0.0001)$.

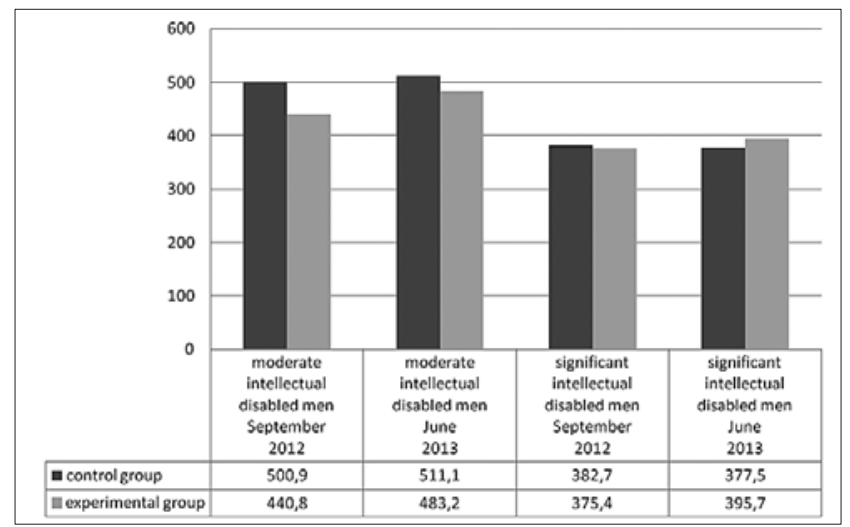

Figure 16. Throwing a $2 \mathrm{~kg}$ medicine ball $(\mathrm{cm})$ 
The 25 meter run test (speed) showed substantial differences in running pace (Fig. 17). Running time, on average, was longer $(0.23 \mathrm{sec}$. and $0.12 \mathrm{sec}$.) in the control group, whereas in the experimental group it was significantly shorter $(-0.47$ sec. and -0.62 sec.; $\mathrm{p}=0.0001)$.

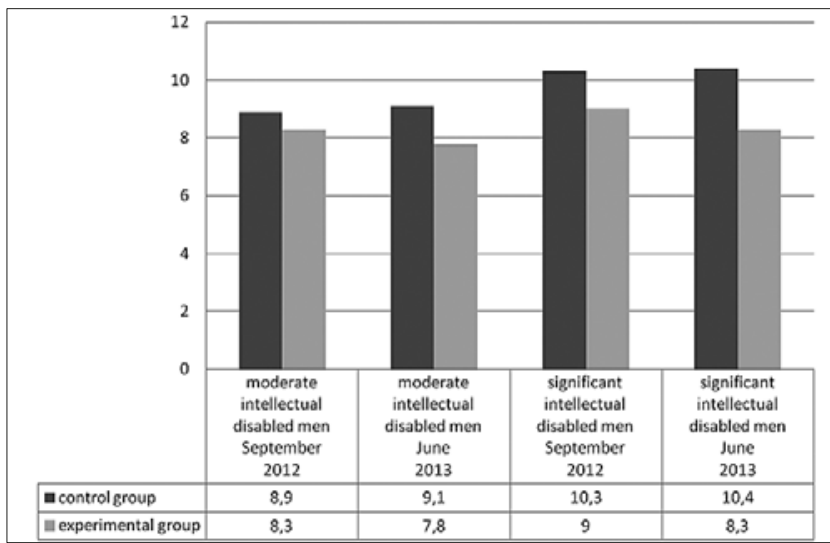

Figure 17. 25 meter run (sec)

Deterioration of the initial results $(-0.63 \mathrm{~cm}$. and $-0.15 \mathrm{~cm})$ was noted in the forward bend test (suppleness) in the control group with moderate and significant intellectual disabilities, whereas in the experimental group they were significantly better $(4.77 \mathrm{~cm}$. and $4.12 \mathrm{~cm})$ (Fig. 18$)$.

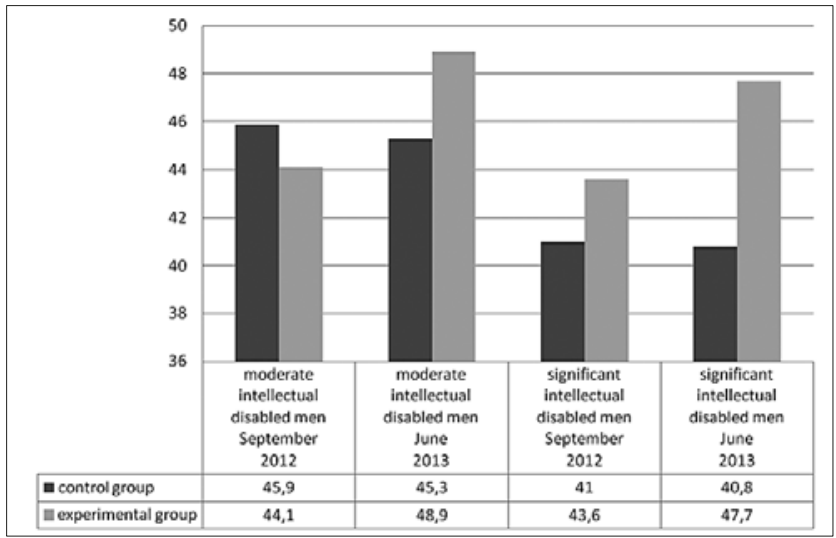

Figure 18. Forward bending in long sit $(\mathrm{cm})$

Similarly, in the supine to long sit test (abdominal muscles strength) the control group with intellectual disabilities obtained worse results ( -0.59 and -0.71$)$, whereas in the experimental group the results were significantly improved (2.86 times better and 3 times better; $\mathrm{p}=0.0001$ ) (Fig. 19).

In both balance tests (raising up on tip-toes with eyes open and closed) (Fig. 20, 21), the control group with intellectual disabilities performed the tests after 10 months in a slightly shorter time $(-0.13 \mathrm{sec}$. and $-0.17 \mathrm{sec}$., and $-0.29 \mathrm{sec}$. and $-0.31 \mathrm{sec}$.$) . The experimental group performed them in a$ significantly longer time (4.59 sec. and $3.55 \mathrm{sec}$.; $\mathrm{p}=0.0001$, and $2 \mathrm{sec}$. and $2.89 \mathrm{sec}$.; $\mathrm{p}=0.0001)$.

In the walking along a 5 meter line with heel-to-toe steps (Fig. 22), the control group with intellectual disabilities performed the exercise in the repeated trial in a slightly longer time $(0.24 \mathrm{sec}$. and $0.44 \mathrm{sec}$.), whereas the experimental group in a significantly shorter time $(-2.36 \mathrm{sec}$. and -2.59 sec.; $\mathrm{p}=0.0003$ ).

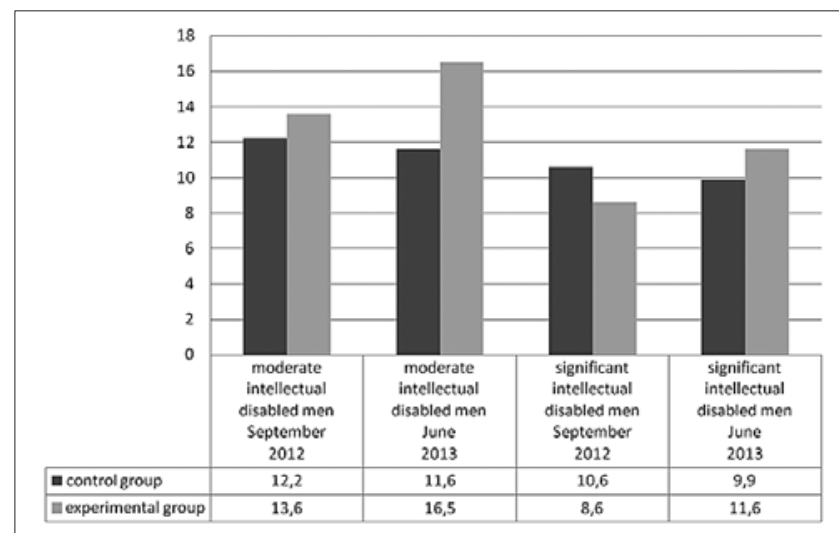

Figure 19. Supine to long sit (sit-ups number)

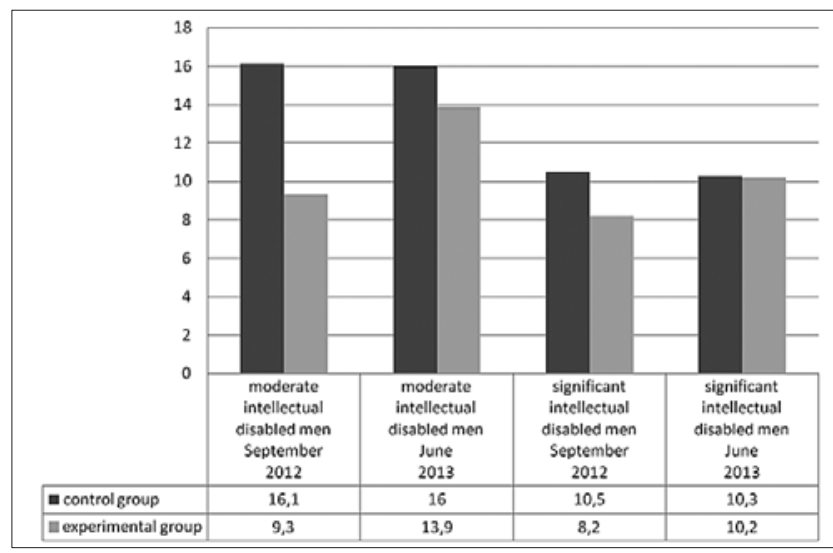

Figure 20. Rising up on tip toes with eyes open (sec)

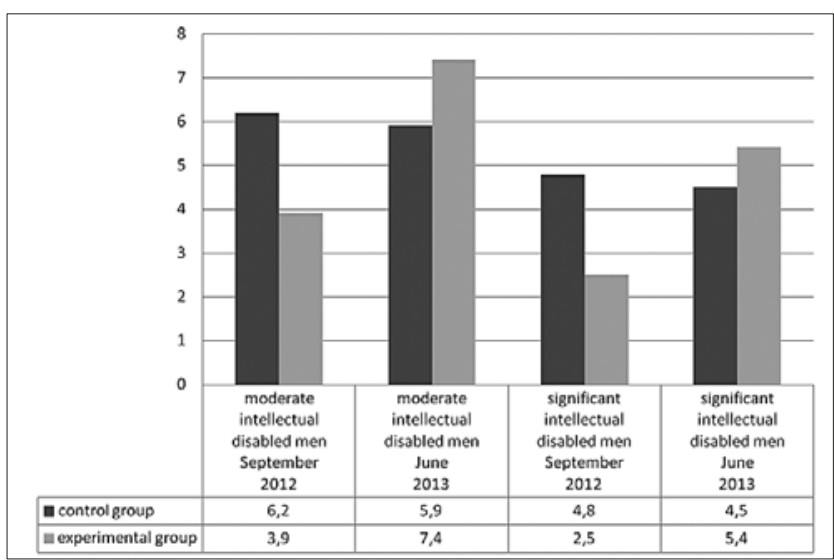

Figure 21. Rising up on tip toes with eyes closed (sec)

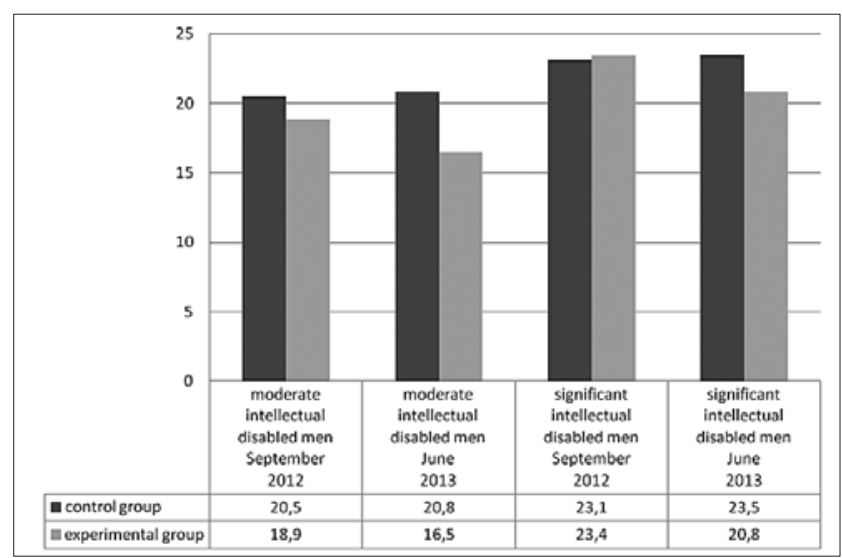

Figure 22. Walking along a 5 meter line with heel-to-toe steps (sec) 
In conclusion. it can be stated that men in the control group with moderate and significant intellectual disabilities, in the repeated tests showed lower or similar level of fitness in almost every test; and men in the experimental group after 10 months of physical activity obtained substantially better results. Therefore, it was observed that feasible physical exercises significantly influenced physical fitness. Better physical fitness, regardless of moderate or significant intellectual disability, resulted in better self-reliance and a better quality of life. The responsiveness of disabled persons to physical stimulation was therefore confirmed.

There are numerous research studies on the importance of physical activity in intellectually disabled persons. Frey (2004) indicates that physical fitness is related to the level of disability: the more severe the disability, the worse the fitness and physical activity. It was also confirmed in a previous study (Ślężyńska et al., 2013) that it is not a matter of more advanced age, but rather that a more severe level of intellectual disability influences the deterioration of physical fitness.

Physical fitness in people with intellectual disability has rarely been a topic of scientific research. Hilgenkamp et al. (2012) in 2009-2010 used pedometers to assess physical activity in 257 subjects with intellectual disability, aged 50 and above, of whom only $16.7 \%$ obtained the recommended standards of 10,000 steps per day. The research highlighted a very low level of physical activity in this group of the population; hence the conclusion to promote physical activity among intellectually disabled people as often as possible. Similar assessments, also with the use of pedometers, were performed by Beets et al. (2011) w2ho also indicated low physical activity in intellectually disabled people. However, there is no possibility for rational comparative studies as pedometers were not used in physical activity assessments in the current strudy.

An interesting study by Elmahgoub et al. (2011) investigated the influence of physical training on obesity in intellectually disabled teenagers who exercised 2 or 3 or more times a week. The research showed significant improvement in physical fitness and beneficial a influence of the exercises on obesity and weight loss. At the same time, the study demonstrated a significant difference between subjects exercising 2 or 3 times a week. Wu et al. (2010) obtained similar results on the beneficial effects of physical exercises, carried out on 146 subjects with intellectual disability, aged $19-67$, who performed fitness exercises for 6 months. The research showed that after the fitness training, their body mass and BMI was decreased, which proved the positive effect of physical exercises on the tissue components of a human body.

There are also methodological proceedings for the physical enhancement of disabled persons (Bilska \& Golanko, 2012; Ślężyński \& Gawlik, 1997), although it is not easy for the disabled to realize such aspirations in their adult life, although there are numerous examples of sport activity and participation in the Special Olympics (Marchewka 2004). The physical activity of intellectually disabled people, especially those with moderate or significant disability, must never be neglected as there are always opportunities for success, as proved by the presented study on the participants of occupational therapy in Silesia.

\section{CONCLUSIONS}

1. Body height during the study remained unchanged, whereas body mass was significantly increased in the control group, and slightly decreased in the experimental group who performed physical exercises for 10 months, regardless of the level of intellectual disability (moderate. significant). Body mass index (BMI) remained unchanged.

2. Physical fitness results were similar in the control group, whereas in standing long jump test and medicine ball throwing test, they were slightly lower. In the experimental group. after 10 months of physical exercises, significant progress in physical fitness was observed. This was especially apparent the in standing long jump test (explosive strength), medicine ball throwing (strength), forward bending (suppleness) and moving from a supine to sitting position (abdominal muscle strength).

3. The study showed that manual workshops, combined with increased physical activity, improve physical fitness and capability to deal with everyday life. Hence, the conclusion that the programme of occupational therapy workshops should be disseminated as it provides significant utilitarian benefits and improvement in the quality of life for intellectually disabled people.

\section{REFERENCES}

1. Beets MW, Pitetti KH. Using pedometers to measure moderate-tovigorous physical activity for youth with an intellectual disability. Disability Health Journal 2011; 4(1): 46-51.

2. Bilska M, Golanko R. Physical acitities develop and iprove articulated speech In inttellectually disables children. In: Movement activities in disabled children and youth. Faculty of Physical Education nad Sport. BiałaPodlaska 2012. p. 91-102.

3. Elmahgoub SS, Lambers S, Stegen SM, van Laethem C, Cambier DC, Calders $P$. The effect of combined exercise training in adolescents who are overweight or obese with intellectual disability: the role of training frequency. Journal Strenght Condition Research 2011;25(8): 2274-2282.

4. Frey GC. Comparison of physical activity levels between adults with and without mental retardation. Journal of Physical Activity and Health 2004; 1: 235-245.

5. Hilgenkamp TI, Reis D, van Wick R, Evenhuis HM. Physical activity levels in older adults with intellectual disabilities are extremely low. Research Development Disabilities 2012; 33(2): 477-483.

6. Marchewka A. The influence of selected factors for sport activities of mentally handicapped people in the mildy and severely degree of retardation. Polish Journal of Sports Medicine 2004; 20(1): 21-28.

7. Nisbet R, Elder J, Miner G. Handbook of statistical analysis and data mining applications. Elsevier Inc. 2009.

8. Skowronski W, Horvat M, Nocera J, Roswal G, Croce R. Eurofit special: European fitness battery score variation among individuals with intellectual disabilities. AdaptedPhysical Activity Quarterly 2009; 26(1): 54-67.

9. Ślężyńska M, Mięsok G, Mięsok K. Physical fitness of people with moderate and considerable intellectual disabilities. Fizjoterapia 2013; 21(3).

10. Ślężyński J, Gawlik K. Physical and locomotor development of mentally handicapped pupils. In: Sport a chance for the disabled. Polish Association of Disabled People. Cracow 1997. p. 287-298.

11. Wu CL, Lin JD, Hu J, Yen CF, Yen CT, Chou YL, Wu PH. The effectiveness of healthy physical fitness programs on people with intellectual disabilities living In a disability institution: six-month short-term effect. Research Development Disabilities 2010; 31(3): 713-717. 


\section{Appendix 1. Additional physical activity programme of the experimental group (E) with moderate and significant intellectual disability}

Basic exercises. Body bends backward and forward. walking on a gym bench, rolling, discipline and order exercises, upper and lower limbs moulding exercises, head rolling and turning exercises. Exercises were performer individually, with a partner, with a tool, on gym benches and gymnastic wall bars.

Athletics with track and field exercises. Low position start, standing position start, sprint running (30 meters), relay running, multiple jumps, long jumps, $2 \mathrm{~kg}$ medicine ball throwing.

Team games. Football, basketball, volleyball with ball catching - basic elements and rules.

Table tennis. Forehand and backhand hits, forehand and backhand serving, singles and doubles play.

Integrative games and plays. Ringo, dodge ball, ring throwing, cooperative team races.

Nordic Walking. Correct technique of using the poles, marching on various types of ground.

Bocca. Correct ball throwing, game rules.

Badminton. Game rules, forehand and backhand hitting, singles and doubles playing.
Table 2. Somatic features of intellectually disabled women in the initial (September 2012) and final (June 2013) tests in control (C) and experimental (E) groups

\begin{tabular}{|c|c|c|c|c|c|c|c|}
\hline \multirow[t]{2}{*}{ Feature } & \multirow[t]{2}{*}{ Group } & \multicolumn{2}{|c|}{$\begin{array}{c}\text { September } \\
2012\end{array}$} & \multicolumn{2}{|c|}{$\begin{array}{l}\text { June } \\
2013 \\
\end{array}$} & \multirow[t]{2}{*}{ D } & \multirow[t]{2}{*}{$\mathrm{p}$} \\
\hline & & $\mathrm{x}$ & $\mathrm{s}$ & $\mathrm{x}$ & $\mathrm{s}$ & & \\
\hline \multicolumn{8}{|c|}{ moderate intellectual disability } \\
\hline \multirow{4}{*}{ Body mass (kg) } & c & 67.93 & 17.59 & 68.95 & 17.59 & 1.02 & 0.0002 \\
\hline & E & 65.45 & 10.34 & 64.27 & 9.88 & -1.18 & 0.085 \\
\hline & $\mathrm{P}$ & \multicolumn{2}{|c|}{0.985} & \multicolumn{2}{|c|}{0.913} & & \\
\hline & C & 25.81 & 5.87 & 26.21 & 5.88 & 0.40 & 0.0002 \\
\hline \multirow[t]{2}{*}{ Body mass index (points) } & E & 25.40 & 3.88 & 24.97 & 3.82 & -0.43 & 0.134 \\
\hline & $\mathrm{P}$ & \multicolumn{2}{|c|}{0.998} & \multicolumn{2}{|c|}{0.955} & & \\
\hline \multicolumn{8}{|c|}{ significant intellectual disability } \\
\hline \multirow{3}{*}{ Body mass (kg) } & C & 67.05 & 19.45 & 68.23 & 20.05 & 1.18 & 0.0002 \\
\hline & $\mathrm{E}$ & 76.47 & 11.01 & 75.47 & 10.59 & -1.00 & 0.022 \\
\hline & $\mathrm{P}$ & \multicolumn{2}{|c|}{0.338} & \multicolumn{2}{|c|}{0.566} & & \\
\hline \multirow[b]{2}{*}{ Body mass index (points) } & C & 26.17 & 7.07 & 26.64 & 7.28 & 0.47 & 0.0002 \\
\hline & $\mathrm{E}$ & 30.50 & 6.00 & 30.08 & 5.74 & -0.42 & 0.015 \\
\hline
\end{tabular}

Table 3. Physical fitness trials of intellectually disabled women in the initial (September 2012) and final (June 2013) tests, in control (C) and experimental (E) groups

\begin{tabular}{|c|c|c|c|c|c|c|c|}
\hline \multirow[t]{2}{*}{ Test } & \multirow[t]{2}{*}{ Group } & \multicolumn{2}{|c|}{$\begin{array}{c}\text { September } \\
2012 \\
\end{array}$} & \multicolumn{2}{|c|}{$\begin{array}{l}\text { June } \\
2013\end{array}$} & \multirow[t]{2}{*}{$d$} & \multirow[t]{2}{*}{$p$} \\
\hline & & $x$ & $S$ & $x$ & $S$ & & \\
\hline \multicolumn{8}{|c|}{ moderate intellectual disability } \\
\hline \multirow{3}{*}{$\begin{array}{l}\text { Walking on a gym } \\
\text { bench (points) }\end{array}$} & C & 3.07 & 0.65 & 3.17 & 0.60 & 0.10 & 0.365 \\
\hline & $\mathrm{E}$ & 3.36 & 0.67 & 3.63 & 0.50 & 0.27 & 0.254 \\
\hline & $\mathrm{P}$ & \multicolumn{2}{|c|}{0.482} & \multicolumn{2}{|c|}{0.118} & & \\
\hline \multirow{3}{*}{$\begin{array}{l}\text { Standing long jump } \\
(\mathrm{cm})\end{array}$} & C & 109.94 & 27.56 & 107.91 & 26.02 & -2.03 & 0.019 \\
\hline & $E$ & 98.54 & 21.75 & 111.72 & 22.48 & 13.18 & 0.0001 \\
\hline & $\mathrm{P}$ & \multicolumn{2}{|c|}{0.737} & \multicolumn{2}{|c|}{0.986} & & \\
\hline \multirow{3}{*}{$\begin{array}{l}\text { Throwing a } 2 \mathrm{~kg} \\
\text { medicine ball }(\mathrm{cm})\end{array}$} & C & 433.35 & 123.90 & 433.78 & 126.90 & 0.43 & 0.997 \\
\hline & $\mathrm{E}$ & 299.45 & 108.02 & 343.36 & 109.93 & 43.91 & 0.0001 \\
\hline & $\mathrm{P}$ & \multicolumn{2}{|c|}{0.061} & \multicolumn{2}{|c|}{0.320} & & \\
\hline \multirow{3}{*}{25 meter run (sec.) } & C & 9.22 & 2.27 & 9.47 & 2.23 & 0.25 & 0.0003 \\
\hline & $\mathrm{E}$ & 8.00 & 1.03 & 7.59 & 0.87 & -0.41 & 0.010 \\
\hline & $\mathrm{P}$ & \multicolumn{2}{|c|}{0.530} & \multicolumn{2}{|c|}{0.166} & & \\
\hline \multirow{3}{*}{$\begin{array}{l}\text { Forward bending in } \\
\text { long sit }(\mathrm{cm})\end{array}$} & C & 50.47 & 7.66 & 49.71 & 7.78 & -0.76 & 0.233 \\
\hline & $E$ & 48.36 & 8.47 & 53.81 & 8.02 & 5.45 & 0.0001 \\
\hline & $\mathrm{P}$ & \multicolumn{2}{|c|}{0.921} & \multicolumn{2}{|c|}{0.610} & & \\
\hline \multirow{3}{*}{$\begin{array}{l}\text { Supine to long sit } \\
\text { (No. of sit-ups) }\end{array}$} & C & 12.84 & 4.45 & 11.57 & 4.09 & -1.27 & 0.0001 \\
\hline & $E$ & 13.09 & 4.15 & 16.00 & 4.17 & 2.91 & 0.0001 \\
\hline & $P$ & \multicolumn{2}{|c|}{0.999} & \multicolumn{2}{|c|}{0.080} & & \\
\hline \multirow{3}{*}{$\begin{array}{l}\text { Rising up on tip- } \\
\text { toes with eyes open } \\
(\mathrm{sec})\end{array}$} & C & 24.24 & 11.94 & 21.38 & 10.22 & -2.86 & 0.0001 \\
\hline & $\mathrm{E}$ & 9.81 & 7.54 & 13.45 & 6.21 & 3.64 & 0.010 \\
\hline & $\mathrm{P}$ & \multicolumn{2}{|c|}{0.011} & \multicolumn{2}{|c|}{0.303} & & \\
\hline \multirow{3}{*}{$\begin{array}{l}\text { Rising up on tip- } \\
\text { toes with eyes } \\
\text { closed (sec) }\end{array}$} & $C$ & 8.35 & 4.01 & 7.85 & 3.53 & -0.50 & 0.195 \\
\hline & $\mathrm{E}$ & 4.18 & 2.67 & 7.54 & 3.17 & 3.36 & 0.0001 \\
\hline & $\mathrm{P}$ & \multicolumn{2}{|c|}{0.045} & 0.5 & 97 & & \\
\hline Walking along a & C & 15.14 & 4.03 & 16.26 & 3.81 & 1.12 & 0.0008 \\
\hline 5 meter line with & $\mathrm{E}$ & 18.72 & 4.31 & 15.54 & 3.26 & -3.18 & 0.0001 \\
\hline$(\mathrm{sec})$ & $\mathrm{P}$ & 0.1 & & & & & \\
\hline
\end{tabular}

\begin{tabular}{|c|c|c|c|c|c|c|c|}
\hline \multirow[t]{2}{*}{ Test } & \multirow[t]{2}{*}{ Group } & \multicolumn{2}{|c|}{$\begin{array}{c}\text { September } \\
2012\end{array}$} & \multicolumn{2}{|c|}{$\begin{array}{l}\text { June } \\
2013\end{array}$} & \multirow[t]{2}{*}{$d$} & \multirow[t]{2}{*}{$\mathrm{p}$} \\
\hline & & $\mathrm{x}$ & $\mathrm{S}$ & $x$ & $\mathrm{~S}$ & & \\
\hline \multicolumn{8}{|c|}{ significant intellectual disability } \\
\hline \multirow{3}{*}{$\begin{array}{l}\text { Walking on the gym } \\
\text { bench (points) }\end{array}$} & $\mathrm{C}$ & 2.82 & 0.71 & 3.05 & 0.64 & 0.23 & 0.078 \\
\hline & $\mathrm{E}$ & 2.68 & 0.58 & 3.42 & 0.60 & 0.74 & 0.0001 \\
\hline & $\mathrm{P}$ & \multicolumn{2}{|c|}{0.913} & \multicolumn{2}{|c|}{0.327} & & \\
\hline \multirow{3}{*}{$\begin{array}{l}\text { Standing long jump } \\
(\mathrm{cm})\end{array}$} & C & 102.67 & 42.72 & 98.50 & 43.20 & -4.17 & 0.353 \\
\hline & $\mathrm{E}$ & 45.52 & 25.63 & 57.21 & 23.62 & 11.69 & 0.006 \\
\hline & $\mathrm{P}$ & \multicolumn{2}{|c|}{0.0002} & \multicolumn{2}{|c|}{0.007} & & \\
\hline \multirow{3}{*}{$\begin{array}{l}\text { Throwing a } 2 \text { kg } \\
\text { medicine ball }(\mathrm{cm})\end{array}$} & C & 287.58 & 73.86 & 282.88 & 84.10 & -4.70 & 0.879 \\
\hline & $\mathrm{E}$ & 258.26 & 88.78 & 295.68 & 82.57 & 37.42 & 0.0004 \\
\hline & $\mathrm{P}$ & \multicolumn{2}{|c|}{0.686} & \multicolumn{2}{|c|}{0.962} & & \\
\hline \multirow{3}{*}{25 meter run (sec.) } & $\mathrm{C}$ & 9.69 & 2.36 & 10.17 & 2.38 & 0.48 & 0.002 \\
\hline & $\mathrm{E}$ & 11.45 & 2.79 & 10.38 & 2.23 & -1.07 & 0.0001 \\
\hline & $\mathrm{P}$ & \multicolumn{2}{|c|}{0.128} & \multicolumn{2}{|c|}{0.993} & & \\
\hline \multirow{3}{*}{$\begin{array}{l}\text { Forward bending in } \\
\text { long sit }(\mathrm{cm})\end{array}$} & $\mathrm{C}$ & 42.11 & 7.65 & 40.67 & 8.92 & -1.44 & 0.015 \\
\hline & $\mathrm{E}$ & 39.78 & 6.37 & 44.57 & 7.02 & 4.79 & 0.0001 \\
\hline & $\mathrm{P}$ & \multicolumn{2}{|c|}{0.793} & \multicolumn{2}{|c|}{0.418} & & \\
\hline \multirow{3}{*}{$\begin{array}{l}\text { Supine to long sit } \\
\text { (No. of sit-ups) }\end{array}$} & $C$ & 9.70 & 4.64 & 8.97 & 3.83 & -0.73 & 0.050 \\
\hline & $\mathrm{E}$ & 6.42 & 3.43 & 8.73 & 3.67 & 2.31 & 0.0001 \\
\hline & $\mathrm{P}$ & \multicolumn{2}{|c|}{0.688} & \multicolumn{2}{|c|}{0.998} & & \\
\hline \multirow{3}{*}{$\begin{array}{l}\text { Rising up on tip- } \\
\text { toes with eyes open } \\
\text { (sec) }\end{array}$} & $C$ & 13.23 & 5.31 & 12.02 & 4.16 & -1.21 & 0.008 \\
\hline & $\mathrm{E}$ & 5.89 & 4.97 & 8.10 & 5.79 & 2.21 & 0.0003 \\
\hline & $\mathrm{P}$ & \multicolumn{2}{|c|}{0.0003} & \multicolumn{2}{|c|}{0.086} & & \\
\hline \multirow{3}{*}{$\begin{array}{l}\text { Rising up on tip- } \\
\text { toes with eyes } \\
\text { closed (sec) }\end{array}$} & C & 5.38 & 3.18 & 5.23 & 2.57 & -0.15 & 0.954 \\
\hline & $\mathrm{E}$ & 2.05 & 1.07 & 4.36 & 1.86 & 2.31 & 0.0001 \\
\hline & $\mathrm{P}$ & \multicolumn{2}{|c|}{0.0007} & 0.7 & & & \\
\hline Walking along a & C & 20.23 & 5.53 & 20.44 & 6.10 & 0.21 & 0.978 \\
\hline 5 meter line with & $E$ & 24.57 & 10.68 & 21.00 & 8.46 & -3.57 & 0.0001 \\
\hline (sec) & $\mathrm{P}$ & & & & & & \\
\hline
\end{tabular}


Table 4. Somatic features of intellectually disabled men in the initial (September 2012) and final. (June 2013) tests in control (C) and experimental (E) groups

\begin{tabular}{|c|c|c|c|c|c|c|c|}
\hline \multirow[t]{2}{*}{ Feature } & \multirow[t]{2}{*}{ Group } & \multicolumn{2}{|c|}{$\begin{array}{c}\text { Sptember } \\
2012 \\
\end{array}$} & \multicolumn{2}{|c|}{ June 2013} & \multirow[t]{2}{*}{$d$} & \multirow[t]{2}{*}{$\mathrm{p}$} \\
\hline & & $x$ & s & $x$ & s & & \\
\hline \multicolumn{8}{|c|}{ moderate intellectual disability } \\
\hline \multirow{3}{*}{ Body mass (kg) } & C & 73.88 & 14.89 & 74.62 & 15.37 & 0.74 & 0.0001 \\
\hline & E & 74.63 & 14.15 & 73.77 & 13.62 & -0.86 & 0.004 \\
\hline & $\mathrm{P}$ & \multicolumn{2}{|c|}{0.999} & \multicolumn{2}{|c|}{0.958} & & \\
\hline \multirow{3}{*}{ Body mass index (points) } & C & 24.89 & 4.82 & 25.32 & 5.12 & 0.43 & 0.068 \\
\hline & E & 24.95 & 3.66 & 24.68 & 3.58 & -0.27 & 0.760 \\
\hline & $P$ & \multicolumn{2}{|c|}{0.997} & \multicolumn{2}{|c|}{0.894} & & \\
\hline
\end{tabular}

\begin{tabular}{|c|c|c|c|c|c|c|c|}
\hline \multirow[t]{2}{*}{ Feature } & \multirow[t]{2}{*}{ Group } & \multicolumn{2}{|c|}{$\begin{array}{c}\text { Sptember } \\
2012\end{array}$} & \multicolumn{2}{|c|}{ June 2013} & \multirow[t]{2}{*}{$d$} & \multirow[t]{2}{*}{$\mathrm{p}$} \\
\hline & & $x$ & s & $x$ & s & & \\
\hline \multicolumn{8}{|c|}{ significant intellectual disability } \\
\hline \multirow{3}{*}{ Body mass $(\mathrm{kg})$} & C & 77.50 & 16.20 & 78.56 & 16.80 & 1.06 & 0.0001 \\
\hline & $\mathrm{E}$ & 74.47 & 17.69 & 73.70 & 17.55 & -0.77 & 0.099 \\
\hline & $P$ & \multicolumn{2}{|c|}{0.953} & \multicolumn{2}{|c|}{0.834} & & \\
\hline \multirow{3}{*}{ Body mass index (points) } & C & 27.02 & 6.34 & 27.38 & 6.56 & 0.36 & 0.0001 \\
\hline & E & 26.08 & 5.00 & 25.83 & 5.08 & -0.25 & 0.124 \\
\hline & $\mathrm{P}$ & & & & & & \\
\hline
\end{tabular}

Table 5. Physical fitness trials of intellectually disabled men in the initial (September 2012) and final (June 2013) tests in control (C) and experimental (E) groups

\begin{tabular}{|c|c|c|c|c|c|c|c|}
\hline \multirow[t]{2}{*}{ Test } & \multirow[t]{2}{*}{ Group } & \multicolumn{2}{|c|}{$\begin{array}{c}\text { September } \\
2012\end{array}$} & \multicolumn{2}{|c|}{$\begin{array}{l}\text { June } \\
2013\end{array}$} & \multirow[t]{2}{*}{ d } & \multirow[t]{2}{*}{$p$} \\
\hline & & $x$ & s & $x$ & s & & \\
\hline \multicolumn{8}{|c|}{ moderate intellectual disability } \\
\hline \multirow{3}{*}{$\begin{array}{l}\text { Walking on a gym } \\
\text { bench (points) }\end{array}$} & C & 3.11 & 0.62 & 3.35 & 0.59 & 0.24 & 0.044 \\
\hline & $\mathrm{E}$ & 3.09 & 0.75 & 3.77 & 0.42 & 0.68 & 0.0001 \\
\hline & $\mathrm{P}$ & \multicolumn{2}{|c|}{0.998} & \multicolumn{2}{|c|}{0.069} & & \\
\hline \multirow{3}{*}{$\begin{array}{l}\text { Standing long jump } \\
(\mathrm{cm})\end{array}$} & C & 118.39 & 42.71 & 117.60 & 41.93 & -0.79 & 0.792 \\
\hline & $\mathrm{E}$ & 109.40 & 51.16 & 124.18 & 48.68 & 14.78 & 0.0001 \\
\hline & $\mathrm{P}$ & \multicolumn{2}{|c|}{0.921} & \multicolumn{2}{|c|}{0.950} & & \\
\hline \multirow{3}{*}{$\begin{array}{l}\text { Throwing } 2 \mathrm{~kg} \\
\text { medicine ball }(\mathrm{cm})\end{array}$} & C & 500.94 & 223.20 & 511.15 & 225.26 & 10.21 & 0.722 \\
\hline & E & 440.81 & 135.90 & 483.22 & 136.99 & 42.41 & 0.004 \\
\hline & $\mathrm{P}$ & \multicolumn{2}{|c|}{0.733} & \multicolumn{2}{|c|}{0.972} & & \\
\hline \multirow{3}{*}{25 meter run (sec) } & C & 8.91 & 2.17 & 9.14 & 2.32 & 0.23 & 0.001 \\
\hline & E & 8.31 & 2.36 & 7.84 & 2.06 & -0.47 & 0.0001 \\
\hline & $P$ & \multicolumn{2}{|c|}{0.871} & \multicolumn{2}{|c|}{0.265} & & \\
\hline \multirow{3}{*}{$\begin{array}{l}\text { Forward bending in } \\
\text { long sit }(\mathrm{cm})\end{array}$} & C & 45.94 & 7.32 & 45.31 & 7.00 & -0.63 & 0.143 \\
\hline & $\mathrm{E}$ & 44.18 & 12.90 & 48.95 & 11.72 & 4.77 & 0.0001 \\
\hline & $P$ & \multicolumn{2}{|c|}{0.831} & \multicolumn{2}{|c|}{0.578} & & \\
\hline \multirow{3}{*}{$\begin{array}{l}\text { Supine to long sit } \\
\text { (No. of sit-ups) }\end{array}$} & C & 12.21 & 4.44 & 11.62 & 4.00 & -0.59 & 0.060 \\
\hline & $\mathrm{E}$ & 13.68 & 5.24 & 16.54 & 5.01 & 2.86 & 0.0001 \\
\hline & $P$ & \multicolumn{2}{|c|}{0.662} & \multicolumn{2}{|c|}{0.001} & & \\
\hline \multirow{3}{*}{$\begin{array}{l}\text { Rising up on } \\
\text { tip-toes with eyes } \\
\text { open (s) }\end{array}$} & $C$ & 16.13 & 11.88 & 16.00 & 11.34 & -0.13 & 0.971 \\
\hline & $E$ & 9.31 & 6.90 & 13.90 & 7.25 & 4.59 & 0.0001 \\
\hline & $P$ & \multicolumn{2}{|c|}{0.134} & \multicolumn{2}{|c|}{0.901} & & \\
\hline \multirow{3}{*}{$\begin{array}{l}\text { Rising up on tip- } \\
\text { toes with eyes } \\
\text { closed (sec) }\end{array}$} & C & 6.21 & 3.91 & 5.92 & 3.21 & -0.29 & 0.676 \\
\hline & $E$ & 3.90 & 1.71 & 7.45 & 2.66 & 3.55 & 0.0001 \\
\hline & $P$ & \multicolumn{2}{|c|}{0.135} & 0.2 & 80 & & \\
\hline Walking along a & C & 20.58 & 7.96 & 20.82 & 8.39 & 0.24 & 0.815 \\
\hline $\begin{array}{l}5 \text { meter line with } \\
\text { heel-to-toe steps }\end{array}$ & $\mathrm{E}$ & 18.90 & 8.18 & 16.54 & 6.17 & -2.36 & 0.0003 \\
\hline$(\mathrm{sec})$ & $\mathrm{P}$ & & 95 & 0.2 & 31 & & \\
\hline
\end{tabular}

\begin{tabular}{|c|c|c|c|c|c|c|c|}
\hline \multirow[t]{2}{*}{ Test } & \multirow[t]{2}{*}{ Group } & \multicolumn{2}{|c|}{$\begin{array}{l}\text { September } \\
2012\end{array}$} & \multicolumn{2}{|c|}{$\begin{array}{l}\text { June } \\
2013\end{array}$} & \multirow[t]{2}{*}{$d$} & \multirow[t]{2}{*}{$\mathrm{p}$} \\
\hline & & $x$ & s & $x$ & s & & \\
\hline \multicolumn{8}{|c|}{ significant intellectual disability } \\
\hline \multirow{3}{*}{$\begin{array}{l}\text { Walking on a gym } \\
\text { bench (points) }\end{array}$} & C & 2.91 & 0.82 & 3.18 & 0.70 & 0.27 & 0.034 \\
\hline & $\mathrm{E}$ & 2.70 & 0.84 & 3.47 & 0.51 & 0.77 & 0.0002 \\
\hline & $P$ & \multicolumn{2}{|c|}{0.845} & \multicolumn{2}{|c|}{0.689} & & \\
\hline \multirow{3}{*}{$\begin{array}{l}\text { Standing long jump } \\
\text { (cm) }\end{array}$} & C & 103.08 & 34.96 & 101.00 & 33.08 & -2.08 & 0.064 \\
\hline & $\mathrm{E}$ & 73.94 & 47.63 & 83.58 & 46.36 & 9.64 & 0.0001 \\
\hline & $P$ & \multicolumn{2}{|c|}{0.121} & \multicolumn{2}{|c|}{0.538} & & \\
\hline \multirow{3}{*}{$\begin{array}{l}\text { Throwing a } 2 \mathrm{~kg} \\
\text { medicine ball } \\
(\mathrm{cm})\end{array}$} & C & 382.79 & 116.92 & 377.50 & 111.55 & -5.29 & 0.044 \\
\hline & $E$ & 375.41 & 152.41 & 395.76 & 153.65 & 20.35 & 0.0001 \\
\hline & $P$ & \multicolumn{2}{|c|}{0.998} & \multicolumn{2}{|c|}{0.974} & & \\
\hline \multirow{3}{*}{25 meter run (sec) } & C & 10.33 & 2.17 & 10.45 & 2.25 & 0.12 & 0.231 \\
\hline & $\mathrm{E}$ & 9.01 & 2.29 & 8.39 & 2.05 & -0.62 & 0.0001 \\
\hline & $P$ & \multicolumn{2}{|c|}{0.311} & \multicolumn{2}{|c|}{0.041} & & \\
\hline \multirow{3}{*}{$\begin{array}{l}\text { Forward bending in } \\
\text { long sit }(\mathrm{cm})\end{array}$} & C & 41.04 & 4.92 & 40.89 & 8.88 & -0.15 & 0.999 \\
\hline & $\mathrm{E}$ & 43.64 & 11.99 & 47.76 & 11.17 & 4.12 & 0.057 \\
\hline & $\mathrm{P}$ & \multicolumn{2}{|c|}{0.809} & \multicolumn{2}{|c|}{0.095} & & \\
\hline \multirow{3}{*}{$\begin{array}{l}\text { Supine to long sit } \\
\text { (No. of sit-ups) }\end{array}$} & C & 10.68 & 3.64 & 9.97 & 3.39 & -0.71 & 0.0002 \\
\hline & $\mathrm{E}$ & 8.64 & 3.87 & 11.64 & 3.83 & 3.00 & 0.0001 \\
\hline & $P$ & \multicolumn{2}{|c|}{0.359} & \multicolumn{2}{|c|}{0.536} & & \\
\hline \multirow{3}{*}{$\begin{array}{l}\text { Rising up on tip- } \\
\text { toes with eyes open } \\
\text { (sec) }\end{array}$} & C & 10.56 & 3.95 & 10.39 & 3.24 & -0.17 & 0.869 \\
\hline & $\mathrm{E}$ & 8.29 & 7.31 & 10.29 & 5.74 & 2.00 & 0.0001 \\
\hline & $\mathrm{P}$ & \multicolumn{2}{|c|}{0.472} & \multicolumn{2}{|c|}{0.100} & & \\
\hline \multirow{3}{*}{$\begin{array}{l}\text { Rising up on tip- } \\
\text { toes with eyes } \\
\text { closed (sec) }\end{array}$} & C & 4.81 & 1.92 & 4.50 & 1.66 & -0.31 & 0.049 \\
\hline & $\mathrm{E}$ & 2.58 & 1.17 & 5.47 & 1.62 & 2.89 & 0.0001 \\
\hline & $\mathrm{P}$ & \multicolumn{2}{|c|}{0.002} & 0.3 & & & \\
\hline Walking along a & C & 23.12 & 9.42 & 23.56 & 9.78 & 0.44 & 0.580 \\
\hline $\begin{array}{l}5 \text { meter line with } \\
\text { heel-to-toe steps }\end{array}$ & $\mathrm{E}$ & 23.41 & 9.55 & 20.82 & 9.28 & -2.59 & 0.0003 \\
\hline$(\mathrm{sec})$ & $P$ & 0.1 & & & & & \\
\hline
\end{tabular}

